Imperial Resilience 



\section{Imperial Resilience}

THE GREAT WAR'S END, OTTOMAN LONGEVITY, AND INCIDENTAL NATIONS

Hasan Kayalı

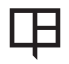

U N I VERSITY OF CALIFOR N A PRES S 
University of California Press

Oakland, California

(C) 2021 by Hasan Kayalı

Library of Congress Cataloging-in-Publication Data

Names: Kayalı, Hasan, author.

Title: Imperial resilience : the Great War's end, Ottoman longevity, and incidental nations / Hasan Kayalı.

Description: Oakland, California : University of California Press, [202I] | Includes bibliographical references and index.

Identifiers: LCCN 2021014322 (print) | LCCN 2021014323 (ebook) | ISBN 9780520343696 (cloth) | ISBN 9780520343702 (paperback) | ISBN 9780520975101 (epub)

Subjects: LCSH: Turkey-History-Mehmed VI, I918-1922. | TurkeyHistory-1918-1960.

Classification: LCC DR589.K355 2021 (print) | LCC DR 589 (ebook) | DDC 956.1/023-dc23

LC record available at https://lccn.loc.gov/2O210I 4322

LC ebook record available at https://lccn.loc.gov/20210I 4323

Manufactured in the United States of America

$\begin{array}{llllllllll}30 & 29 & 28 & 27 & 26 & 25 & 24 & 23 & 22 & 21\end{array}$

$\begin{array}{llllllllll}\text { IO } & 9 & 8 & 7 & 6 & 5 & 4 & 3 & 2 & \text { I }\end{array}$ 
Dedicated to the memory of my parents, Mibriver and Reşid Kayalı 
